\title{
日常管理者に対する緬羊の行動反応に見られる 此雄差ならびに年齢の影響
}

\author{
竹村勇司・川本佳枝 \\ 東京農工大学農学部, 府中市 183-8509
}

(2009 年 11 月 16 日受理)

\section{緒言}

家畜管理においては，毎日の給餌や掃除などの ように管理者が家畜に接近あるいは接触して行う 作業が多い。また, 体重計測, 削蹄, 毛刈り, 駆 虫, 分娩管理, 治療などの際には, 管理者は家畜 を誘導, 捕獲, 保定して処置をする必要があり, 家畜との接触は不可避である。こうした管理作業 が順調に行われるかどうかは，家畜の人に対する 行動反応に大きく依存しており, 家畜の取り扱い やすさを決める大きな要因となっている。

家畜の対人行動反応は, 家畜が管理者に対して どのような考えや感情を抱いているかによって变 わってくると考えられる。すなわち，管理者が及 ぼす利害に対する関心や興味の度合い, 管理者に 対する親近感, 信頼感, 期待感, あるいはその逆 の不安感, 恐怖心, 警戒心などといったものが対 人行動反応を修飾していると推定される。家畜が 管理者に対して抱くこうした心理状態の評価, あ るいは家畜の取り扱いやすさの指標として, 現 在, 逃走距離 ${ }^{1,2)}$, 接近距離 ${ }^{2}$, あるいは捕獲時間 ${ }^{3)}$ などがよく用いられている。

人に対する不安, 恐怖, 警戒といった負の感情 は家畜のストレスとなるため, 家畜の取り扱いや すさといった家畜管理上の関心に止まらず，生産 性への影響について屯関心が持たれている ${ }^{4-7)}$ 。対 人行動反応は, 人への馴致経験の有無 ${ }^{3,8-10)}$, 人之 接する時間の長短や機会の頻度 ${ }^{11-13)}$, 家畜に対す
る管理者の態度-6,14) などによって変わってくる ことが報告されている。しかしながら，家畜側の 要因として考えられる品種, 性別, 年齢などの影 響12,15)についてはまだ未解明な点が多い。 本研究では, 日常管理者に対する緬羊の行動反 応について, 雌雄差や年齢によってどのような違 いがあるかを明らかにする目的で, はじめ, 給餌 時を想定して管理者に対する接近や逃走の様子, ついで, 捕獲時を想定し捕獲に要する時間の測定 を行った。

\section{材料および方法}

\section{1. 実験時期および場所}

実験は, 2004 年の秋に本学農学部内の緬羊屋外 飼育実験場で行った。

\section{2. 被験動物}

コリデール種の雄（年齢 2 13 歳）および雌 (0 〜 13 歳） 10 頭ずつ計 20 頭を供試した。動物は全 て上記実験場で生産されたものである。例年, 出 産から 1 2 週間は母子と屯に屋内房で飼育され た後, 屋外パドックに移動させた。雄子羊は初め 母羊と同じ群で飼育された後, 夏までに雄群に加

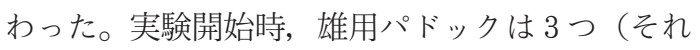
ぞれ 4 頭, 4 頭, 2 頭収容), 雌用パドックは $2 つ$ (それぞれ 6 頭，4頭収容）であった。パドックは 面積が縦横 $10 \mathrm{~m}$ 前後で, 南面の両隅に出入り口 があり，高さ約 $1.2 \mathrm{~m}$ の金網フェンスで囲われて いた。給餌は毎日午前中に行い, 実験中は餌箱を

Jpn. J. Sheep Sci., 46 : 20-27. 2009

Differences in behavioral responses to daily caretakers observed between male and female sheep and their age effects

Yuji TAKEMURA and Yoshie KaWAmoto

Faculty of Agriculture, Tokyo University of Agriculture and Technology, Fuchu-shi 183-8509, Japan 
パドックのほぼ中央部に置いた。

\section{3. 実 験 者}

給餌やパドックの掃除などの動物の世話を日常 的に行っている 2 名（成人男女各 1 名）が実験に 参加した。

\section{4. 測定項目および実施方法}

1）接近距離（approach distance）の測定 接近距離の定義としては, 人が動かずに立って いる時に, 動物が人によ゙こまで接近してくるかと いう意味で用いた2)。

まず， 1 人の実験者 (接近対象者) がパドック南 面西隅にある出入り口前に近づいて 1 分間佇立 し, その間, 後方にいるもう 1 人の実験者（観察 者）が各個体の接近距離を測定した。次に，接近 対象者が出入り口からパドックに入り出入り口前 で 1 分間佇立し, その間, 観察者は各個体の接近 距離を測定した。距離の測定は目視で行い,フェ ンスに $1 \mathrm{~m}$ ごとの印を付けた他, パドック内にお ける出入り口からの距離を前もって測定し目安と した。

測定は 1 日につき, 採食の前, 中, 後の 3 条件 でそれぞれ 1 回ずつ行った。また, 接近対象者と 観察者は, 1 日ごとに交代で行い, 3 日ずつ, 計 6 日間行った。

2）逃走距離（flight distance）の測定

逃走距離の定義としては, 人が動物にどこまで 接近したら動物が逃走を開始するかという意味で 用いた ${ }^{1,2)}$ 。

パドック内で， 1 人の実験者 (接近者) が $0.5 \mathrm{~m} /$ secのゆっくりとした歩調で各個体に接近しなが ら接触を試みた。接触できた場合は $0 \mathrm{~m}$, 接触前 に動物が逃走を開始した場合はその時点での距離 を逃走距離とした。逃走距離の測定は, パドック の外にいるもう 1 人の実験者 (観察者) が目視で 行った。測定は, 接近距離と同様に, 1 日につき, 採食の前，中，後の 3 条件でそれぞれ 1 回ずつ, 接近者と観察者を交代で 3 日ずつ, 計 6 日間行っ た。

3）捕獲時間（capture time）の測定 測定は午後に行った。 $8 \mathrm{~m} \times 8 \mathrm{~m}$ の正方形のパ ドックに動物を入場させ，ロープを用いて捕獲を 試みた。ロープは長さ $1.3 \mathrm{~m}$ で, 両端を左右の手 でそれぞれ持って使用した。パドックには南面西
隅および西面北隅に出入り口があった。

まず，実験者の 1 人が，南面出入り口前のパ ドック内でロープを持って待機し，もう 1 人の実 験者が西面出入り口から動物をパドック内に入場 させた。動物の入場から実験者が動物の碵にロー プをかけるまでの時間を捕獲時間とした。ただ し, 実験者が 1 人で 2 分以内に捕獲できなかった 場合は，もう 1 人の実験者屯入場して 2 人がかり で捕獲を試み， 2 人の実験者のどちらかが捕獲に 成功するまで行った。

測定は動物 1 個体当り 1 日 2 回実施し, 2 日間, 計 4 回行った。初日の 2 回の測定は, どちらむ一 方の実験者 $\mathrm{A}$ が最初に捕獲を試み, 失敗した場 合は残りの実験者 B が捕獲に加わった。2 日目の 測定は 2 回と屯実験者 $\mathrm{B}$ が最初に捕獲を試み, 失 敗した場合は実験者 A が捕獲に加わった。

\section{5. デー夕処理}

個体ごとに, 全測定值から中央值を求めて各個 体の代表値とし, 雌雄差および年齢の影響につい て検討した。統計的な解析を行う場合には， , ン・パラメトリックな検定法を用い, 危険率が $5 \%$ 未満の場合に統計的に有意な差があると判定 した。此雄群間の差の検定にはマン・ホイットニー 検定を用い, 採食前後間の差の検定にはウィルコ クソン順位和検定を用いた。また，採食前中後間 の差の検定にはフリードマン検定を用い, 有意差 がある場合は，さらにスチューデント・ニューマ ン・クール検定 (SNK 検定) で多重比較を行った。

\section{結果}

\section{1. 雌雄群間の比較}

1) 接近距離

採食前中後の 3 条件の内，採食中においては， 動物は採食に夢中で人に対する接近行動は見られ なかった。そのため, 解析は採食前後の 2 条件に ついて行った。

Fig. 1A に実験者がパドック外に佇立した場合 の測定結果を示す。採食前にパドックの外に立つ とパドック内に散らばっていた緬羊は近寄ってき た。一方採食後は雄で若干近づく傾向があったも のの, 雌はほとんど近づかなかった。雌雄とも採 食前は採食後と比較して有意に小さい值を示し た。また，採食前後とも雄が雌よりも接近距離が 
短い傾向で，採食前は有意に小さい值となった。 なお，採食前の雄群の接近距離の中央值は $0.4 \mathrm{~m}$ であったが, 実験者と動物とがフェンスで物理的 に隔てられているためこれ以上は接近できなかっ たことによるあのである。

Fig. 1Bに実験者がパドック内に佇立した場合 の測定結果を示す。採食前はパドック内に入るこ とにより雄では多くの個体が実験者に接触した が，雌では後退行動を示す個体が多かった。パ

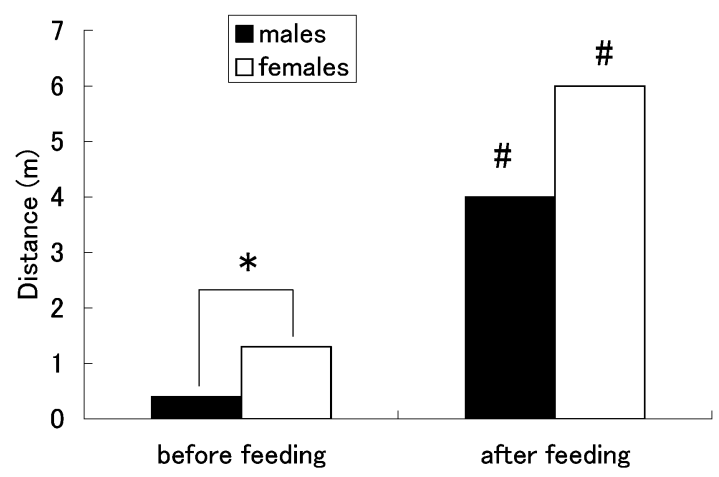

Fig. 1A. Approach distance to a caretaker standing outside the paddock.

Values are medians of 10 animals. * : Significant difference between male and female groups by Mann-Whitney-U-test $(\mathrm{P}<0.05)$. \# : Significant difference from that in before-feeding by Wilcoxon-t-test $(\mathrm{P}<0.05)$.

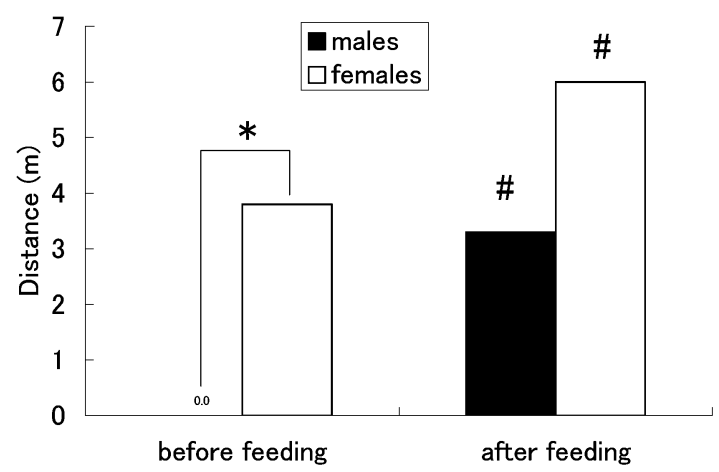

Fig. 1B. Approach distance to a caretaker standing inside the paddock.

Values are medians of 10 animals. * : Significant difference between male and female groups by Mann-Whitney-U-test $(\mathrm{P}<0.05)$. \# : Significant difference from that in before-feeding by Wilcoxon-t-test $(\mathrm{P}<0.05)$.
ドック外に佇立した場合と同様, 雌雄ともに採食 前は採食後と比較して有意に小さい值を示した。 また，採食前後と屯雄が雌よりも接近距離が短い 傾向で，採食前は有意に小さい值となった。

実験者がパドック外にいる場合 (Fig. 1A) と中 にいる場合 (Fig. 1B) で接近距離を比較すると, 雄では採食前 (外 $0.4 \mathrm{~m}$, 中 $0.0 \mathrm{~m}$ ), 後 (外 $4.0 \mathrm{~m}$, 中 $3.3 \mathrm{~m}$ ）とも大きな違いは見られなかった。一 方, 雌では, 採食後については実験者が外にいる 場合 $(6.0 \mathrm{~m})$ と中にいる場合 $(6.0 \mathrm{~m})$ とで違いは 認められなかったが，採食前は実験者がパドック 内に入ったことによって接近距離が長くなる傾向 であった（外 $1.3 \mathrm{~m}$, 中 $3.8 \mathrm{~m}$ )。

\section{2）逃走距離}

Fig. 2 は採食前中後における逃走距離を示した あのである。雄の中央值は 3 条件とあ $0.0 \mathrm{~m}$ で多 くの個体に接触が可能であった。一方, 雌では採 食中のみ $0.0 \mathrm{~m}$ であり, 採食前は $1.3 \mathrm{~m}$, 採食後は $0.5 \mathrm{~m}$ で, 採食中の值は採食前後の值に比べて有 意に小さかった。䧳雄間では採食前に雄は雌より も有意に小さい值を示した。

3）捕獲時間

Fig. 3 に捕獲に要した時間を雌雄で比較したも のを示す。雄では全く逃げない個体も多く短時間

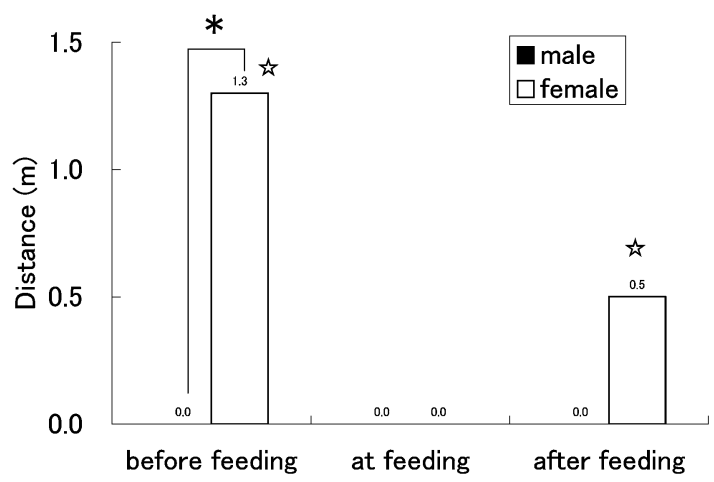

Fig. 2. Flight distance to a caretaker approaching at a constant speed of $0.5 \mathrm{~m} / \mathrm{sec}$.

Values are medians of 10 animals. * : Significant difference between male and female groups by Mann-Whitney-U-test $(\mathrm{P}<0.05)$. In female group, significant differences were found among before-, at-, and after-feeding by Freedman's $\chi^{2}$ r-test $(\mathrm{P}<0.05)$. 5 : Significant difference from that in at-feeding by Student-Newman-Keuls-test $(\mathrm{P}<0.05)$. 
に捕獲できたが，䧳ではほとんどが逃走し，捕獲 に時間を要した。中央值は雄の 6.4 秒に対して, 雌は 52.8 秒であり, 䧳は雄に比べて有意に長かっ た。

\section{2. 年齢との関係}

1) 接近距離

Fig. 4 は採食前に実験者がパドック外に佇立し た場合の接近距離と年齢との関係を雌雄別に示し たあのである。同年齢で比較すると雌は雄と比べ て相対的に接近距離が長い傾向にあった。また, 年齢によって接近距離は変化し, 3〜4 歳の頃に接

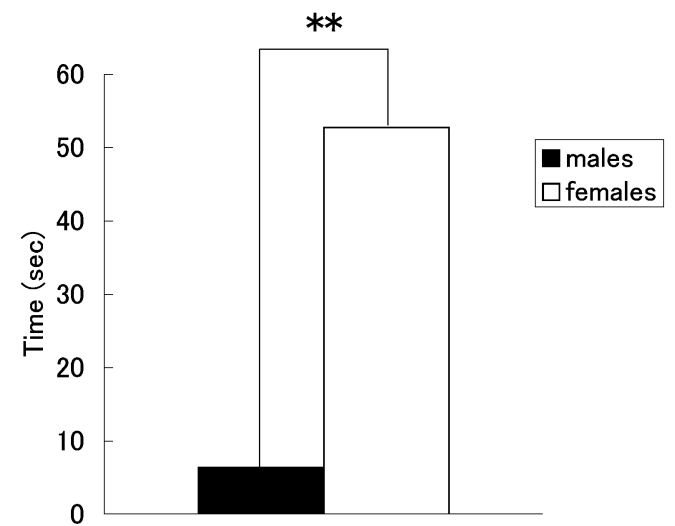

Fig. 3. Capture time.

Values are medians of 10 animals. ${ }^{* *}$ : Significant difference between male and female groups by Mann-Whitney-U-test $(\mathrm{P}<0.01)$.
近距離がもっとも長くなる傾向が認められた。ま た，採食前は実験者がパドック内に佇立した場合 屯同様の傾向であった。採食後は，実験者がパ ドック内外どちらで佇立した場合も, 雌はほとん ど移動行動がなく, 雄は若干接近するものの年齢 との関係は不明瞭であった。

\section{2）逃走距離}

Fig. 5 は採食中の逃走距離と年齢との関係を雌 雄別に示したものである。雄では 10 頭とも逃走 せず接触することが可能であった。一方, 雌では 採食中であ逃走した個体があり，3〜4歳の個体は 接触することができなかった。また, 採食前後と 屯同様の傾向であった。

3）捕獲時間

Fig. 6 は捕獲時間と年齢との関係を雌雄別に示 したあのである。同年齢で比較すると雌は雄と比 べて相対的に捕獲時間が長い傾向にあった。ま た，捕獲に要する時間は年齢によって変化してお り, 3〜4歳の頃にもっと屯長くなる傾向が認めら れた。

\section{考察}

接近距離は, 距離が短いほど人に対する強い関 心や親近感を抱いており, 逆に距離が長いほど関 心が低いかまたは警戒心が強いことを推測させ る。逃走距離は, 距離が長いほど人を強く警戒し ており，逆に距離が短いほど警戒心が弱いことが

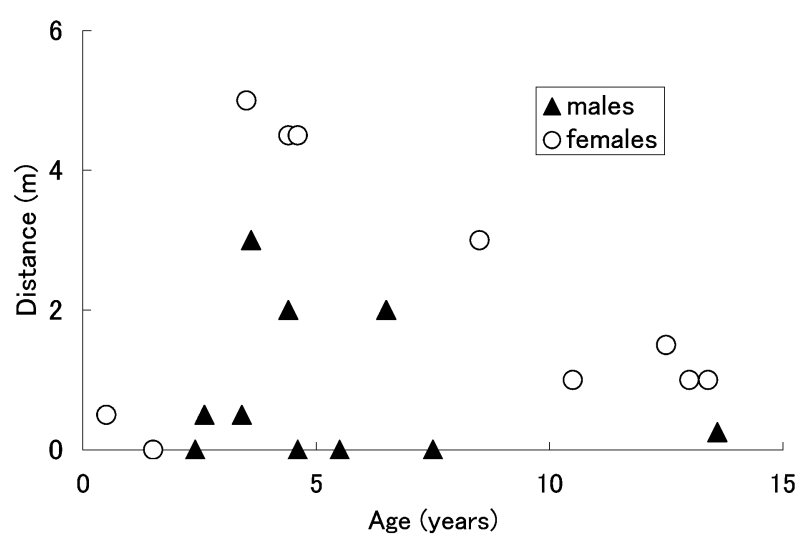

Fig. 4. Relationship between the approach distance and the age.

The figure shows the data before feeding for a caretaker standing outside the paddock. Two kinds of plots indicate the male and the female data of 10 animals, respectively. 


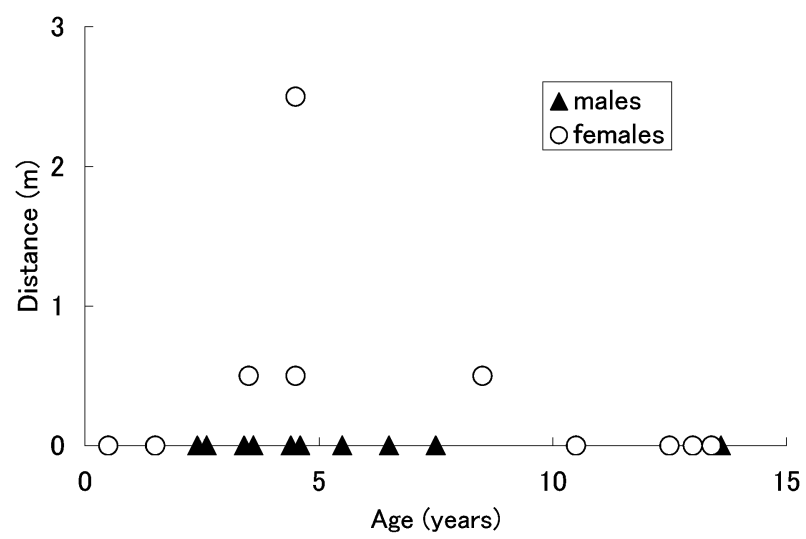

Fig. 5. Relationship between the flight distance and the age.

The figure shows the data at feeding. Two kinds of plots indicate the male and the female data of 10 animals, respectively.

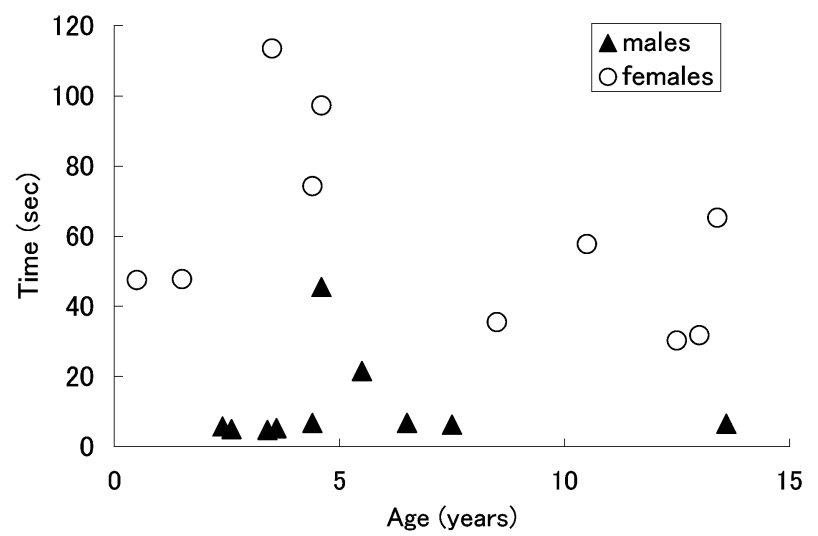

Fig. 6. Relationship between the capture time and the age.

Two kinds of plots indicate the male and the female data of 10 animals, respectively.

推測される。捕獲時間については，時間が長いほ ど人を強く警戒しており，逆に短いほど警戒心が 弱いことが推測される。

本実験で供試された動物は, 雌雄とも採食前は 管理者に対して接近行動を示したこと, また, 雄 はほとんど逃走行動を示さず, 雌でも採食中は多 くの個体が逃走行動を示さなかったことから，䧳 雄とも管理者に対し程度の差はあっても信頼感を 持っているあのと推測された。

接近距離は, 雌が雄よりあ長い傾向で, 特に採 食前は管理者がパドックの外にいる場合も中にい る場合も有意に長かったことから，雌が雄よりも 管理者に対する警戒心が強いものと推測された。
雌では管理者がパドック内に入ったことによって 後退行動を示したことからも, 雌の警戒心が雄よ りも強いことが推測され，また，人との間のフェ ンスの存在が動物の警戒心を低下させる作用のあ ることが示唆された。

採食中は, 雌雄とあパドックの外あるいは中に 佇立している管理者に対する接近行動が見られな かったことから，採食中は管理者に対する関心が ほとんど無くなることが示された。また, 雌雄と 屯, 採食前の接近距離が採食後より屯有意に短 かったのは, 動物が空腹状態にあり, 給慨を行う 日常管理者に対する関心が高かったことが原因と 考えられた。 
逃走距離は, 雄で採食前, 中, 後とも中央值が $0.0 \mathrm{~m}$ であったのに対して, 雌ではそれぞれ, $1.3 \mathrm{~m}$, $0.0 \mathrm{~m}, 0.5 \mathrm{~m}$ であったことから, 雄がほとんど管 理者を警戒してないのに対して，雌は採食中を除 くと管理者を警戒していること，採食中は警戒心 が低下することが示唆された。

捕獲実験においては, 雄の多くは逃走しなかっ たが, 雌の多くは逃走した。此倠の捕獲時間は 52.8 秒で, 雄の 6.4 秒と比べ有意に長く, 雌は雄より も警戒心が強いことが裏付けられた。

雌が雄よりも警戒心が強い理由のひとつには, 䧳が雄と比べ一般的に逃走に必要な運動能力ある いは外敵との闘争能力が小さいことが理由として 考えられる。動物学では一般的に, 逃走距離また は逃走開始距離（flight initiation distance）は, 接近してくる捕食者に対して逃走を開始する距離 と定義されており ${ }^{16)}$ ，捕食者から安全に逃げるた めに必要な距離とみなすことができる。体重の異 なる品種を用いて, 成雌羊の捕食動物刺激に対す る逃走距離を調べた研究では, 体重が軽い品種ほ ど逃走距離が長く, よい強い警戒反応を示すこと が報告されており ${ }^{17)}$, 運動能力や闘争能力の低い 動物の逃走距離が長くなることが予想される。

個体の接近距離と年齢との関係を検討した結果 (Fig. 4), 接近距離は 3 4 歳頃にもっとも長く, また, 雌の逃走距離と年齢との関係を検討した結 果（Fig. 5) も逃走距離は 3〜4 歳頃にもっとも長 く, さらに, 捕獲時間と年齢との関係を検討した 結果（Fig. 6）においても, 捕獲時間は 3〜4 歳頃 にあっとも長くなることがわかった。これらの結 果から, 人に対する警戒心は年齢によって变化し, 3〜4歳頃にもっとも強くなるあのと推測された。

こうした成長・加齢にとあなう変化がなぜ生じ たかについては, 可能性として, 動物が出生から しばらくの間は群から離れ管理者の下で飼育され る期間が存在したため管理者との信頼関係が築か れたこと, その後, 群に戻ってからは管理者との 接触機会が減じたため次第に関係が希薄化し, 3 〜4 歳頃までこの傾向が続いたが, さらに年齢が 進むと，管理者と過ごした期間が長くなるので慣 れが生じて警戒心が次第に弱まったためではない かと考えられる。また，雌では年齢が進むととも に出産による人への依存体験が増えることもひと
つの理由として考えられる。

今まで，家畜の警戒心に及ぼす性別や年齢之 いった個体側要因の影響を明確に示した報告はほ とんど見当たらない。本研究で此雄差や年齢の影 響が明瞭に示されたのは, 対象とした個体群が出 生後同一の飼育環境下で飼育されており, 年齢構 成も 0 13 歳までと緬羊のライフスパンの大部分 をほぼ均一にカバーしていたことによるものと考 えられる。

\section{結論}

本研究で得られた成績から, 緬羊の人に対する 警戒心は, 成長・加齢にともなって変化し，3〜4 歳頃をピークに高まるものと推測される。また, 年齢が同じならば雌が雄よりあ警戒心が強く, 相 対的に雌は雄よりあ人に対する警戒心が強いと言 える。

\section{要 約}

本研究は日常管理者に対する緬羊の行動反応に おける雌雄差および年齢の影響を明らかにするこ とを目的とした。縦横 $10 \mathrm{~m}$ 前後の 5 つの屋外パ ドックで周年飼育されているコリデール種雄 3 群 計 10 頭（2１3 歳）および此 2 群計 10 頭（ 0 13 歳）を供試し，日常的に給餌や掃除などの世話を している成人男女各 1 名で実験を行った。測定項 目は，1）採食前中後にパドックの外または中に佇 立している管理者に対する接近距離, 2) 採食前中 後にパドック内で毎秒 $0.5 \mathrm{~m}$ の速度で管理者が動 物に近づく時の逃走距離, 3） $8 \mathrm{~m} \times 8 \mathrm{~m}$ の区画内 に㧍ける捕獲時間とした。採食中は雌雄とも接近 行動が見られなかったことから，採食中は管理者 に対する関心が低下することが示唆された。採食 後の接近距離 (中央值) は, パドック外管理者に対 して雄 $4.0 \mathrm{~m}$, 雌 $6.0 \mathrm{~m}$, パドック内管理者に対し て雄 $3.3 \mathrm{~m}$, 此 $6.0 \mathrm{~m}$ で, 雄が雌に比べて短い傾向 であった。採食前は，管理者がパドック外にいる 場合は雄が $0.4 \mathrm{~m}$, 雌が $1.3 \mathrm{~m}$ であった。管理者が パドック内に入ると雌は後退行動を示した。接近 距離は雄 $0.0 \mathrm{~m}$, 此 $3.8 \mathrm{~m}$ で, いずれす雄が雌に比 べ有意に短かった $(\mathrm{P}<0.05)$ 。また, 雌雄とも採 食前は採食後に比べ有意に短かった $(\mathrm{P}<0.05)$ 。 採食前の接近距離が短かった理由は, 給䬺に対す 
る期待によって管理者に対する関心が高まるため と考えられた。此倠の接近距離が雄よりあ長かった のは, 雌が雄よりも管理者に対する警戒心が強い ことが原因と推測された。管理者がパドック内に 入ることにより䧳が後退したことから雌の警戒心 が雄よりも強いこと, また, 管理者との間のフェ ンスの存在は警戒心を低下させる作用のあること が示唆された。雄の逃走距離（中央值）は採食前 中後とも $0.0 \mathrm{~m}$ であったが，䧳ではそれぞれ， 1.3 $\mathrm{m}, 0.0 \mathrm{~m}, 0.5 \mathrm{~m}$ で採食前後は採食中よりも有意に 長かった $(\mathrm{P}<0.05)$ 。また, 雌の採食前の值は雄 よりも有意に大きかった $(\mathrm{P}<0.05)$ 。これらのこ とから，雄がほとんど管理者を警戒していないの に対して，雌は採食中を除くと管理者を警戒して いること，また，採食中は警戒心が低下すること が示唆された。雌の捕獲時間（中央值）は 52.8 秒 で, 雄の 6.4 秒と比べ有意に長く $(\mathrm{P}<0.01)$, 䧳は 雄よりも警戒心が強いことが裏付けられた。個体 の年齢之接近距離, 逃走距離, および捕獲時間と の関係を検討した結果, 3〜4 歳頃に, 接近距離, 逃走距離, および捕獲時間のどれもが最も長くな ることが明らかになった。このことから緬羊の人 に対する警戒心は 3〜 歳頃にもっとも強くなる あのと推測された。

\section{文献}

1）佐藤衆介・近藤誠司 - 田中智夫 - 楠瀬 良編著, 家畜行動図説. 朝倉書店. 東京. 1995.

2) Purcell, D., C.W. Arave and J.L. Walters, Relationship of three measures of behavior to milk production. Applied Animal Behaviour Science, 21 : 307-313. 1988.

3）小迫孝実・井村 毅, 黒毛和種子牛に対する生後 3 日間のヒトの接触処理がその後の対人反応に及 ぼす影響. 日畜会報, 70 : J409-J414. 1999.

4) Rushen, J., A.M.B. De Passille and L. MunksGAARD, Fear of people by cows and effects on milk yield, behavior, and heart rate at milking. J. Dairy. Sci., 82 : 720-727.1999.

5) Hemsworth, P.H., G.J. Coleman, J.L. Barnett and S. BorG, Relationships between humananimal interactions and productivity of commercial dairy cows. J. Anim. Sci., 78 : 2821-2831. 2000.
6) Hemsworth, P.H., G.J. Coleman, J.L. Barnett, S. Borg and S. Dowling, The effects of cognitive behavioral intervention on the attitude and behavior of stockpersons and the behavior and productivity of commercial dairy cows. $J$. Anim. Sci., $80: 68-78.2002$.

7) Uetake, K., S. Morita, S. Hoshiba and T. TANAKA, Flight distance of dairy cows and its relationship to daily routine management procedures and productivity. Animal Science Journal, $73: 279-285.2002$.

8）安部直重 - 高崎宏寿 - 久保田義正, 子牛の哺乳期 に打ける馴致処理がヒトへの逃避反応性および模 擬闘争行動に及ぼす影響. 日本家畜管理学会誌, $36: 143-150.2001$.

9) Markowitz, T.M., M.R. Dally, K. Gursky and E.O. PRICE, Early handling increases lamb affinity for humans. Animal Behaviour, 55 : 573587. 1998.

10) Uetake, K., S. Yamaguchi and T. Tanaka, Psychological effects of early gentling on the subsequent ease of handling in lambs. Animal Science Journal, 71 : 515-519. 2000.

11）植竹勝治 - 森田 茂 ・清水悟史 $\cdot$ 干場信司 $\cdot$ 矢用 健一・瀬尾哲也・久米新一, 酪農現場での乳牛の 搾乳・乾乳期に打ける管理作業時間之逃走距離。 日本家畜管理学会誌，34:14-15. 1998.

12）近藤誠司・谷川珠子 ・田中美穂・泰 寛 $\cdot$ 大久 保正彦, 放牧地に求ける肉用牛群㧍よび乳用牛群 のヒトに対する Flight distance. 日本家畜管理学 会誌, $35:$ 30-31. 1999.

13) Uetake, K., S. Morita, Y. Kobayashi, S. Hoshiba and T. TANaKa, Approachability and contact behavior of commercial dairy calves to humans. Animal Science Journal, 74 : 73-78. 2003.

14) Munksgaard, L., A.M. De Passille, J. Rushen, M.S. Herskin and A.M. Kristensen, Dairy cows' fear of people : social learning, milk yield and behaviour at milking. Applied Animal Behaviour Science, 73 : 15-26. 2001.

15）中西良孝 - 前原康伯 - 梅津頼三郎 - 増田泰久 - 五 斗一郎, 肉用牛の管理者に対する逃避反応につい て, とくに供試牛の性, 月齢, 社会構造及び飼養 条件との関連. 日本家畜管理研究会誌, $26: 16^{-}$ 17. 1990.

16) Stankowich, T. and D.T. Blumstein, Fear in ani- 
mals : a meta-analysis and review of risk assessment. Proceedings of the Royal Society $B$, 272 : 2627-2634. 2005.

17) Hansen, I.I., F. Christiansen, H.S. Hansen, B.
BRAASTAD and M. BAKKEN, Variation in behavioural responses of ewes towards predatorrelated stimuli. Applied Animal Behaviour Science, 70 : 227-237. 2001.

\section{Summary}

The aim of this study was to elucidate the difference between male and female sheep in their behavioral response to daily caretakers and how the age of animals influences the response. Ten Corriedale males ( 2 to 13 years old) in 3 groups and 10 Corriedale females ( 0 to 13 years old) in 2 groups kept all year round in 5 outdoor paddocks of $c a .10 \times 10$ square meters, respectively, were used. Experiments were performed by 2 daily caretakers (male and female adults). Three kinds of measurements were made $: 1$ ) approach distance to a person standing outside or inside the paddock before, at, and after feeding ; 2) flight distance to a person approaching the animals in the paddock at a speed of $0.5 \mathrm{~m} / \mathrm{sec}$ before, at, and after feeding ; 3 ) capture time by one or 2 persons in an $8 \times 8$ square meters fenced area. Since no approaching behaviors occurred in animals at feeding, animals' interest for caretakers seemed to be lowered at feeding. Before feeding, approach distances (medians of 10 animals) to a person standing outside the paddock were $0.4 \mathrm{~m}$ in males and $1.3 \mathrm{~m}$ in females, respectively. When the person entered the paddock, female sheep retreated to some extent from the person. The approach distances measured inside the paddock were $0.0 \mathrm{~m}$ in males and $3.8 \mathrm{~m}$ in females, respectively. After feeding, approach distances measured outside and inside the paddock were inclined to be shorter in males $(4.0 \mathrm{~m}$ and $3.3 \mathrm{~m})$ than in females $(6.0 \mathrm{~m}$ and $6.0 \mathrm{~m})$. In both males and females, approach distances before feeding were significantly $(\mathrm{P}<0.05)$ shorter than those observed after feeding. The short approach distances before feeding may reflect the animals' expectation of feeding by the caretakers. From the longer approach distance of females, it is presumed that they have stronger wariness of people than males. Retreat of females observed when caretakers entered the paddock also suggests the stronger wariness of people in females. A fence separating animals from people may have a lowering effect on animals' wariness of people. Flight distances observed before, at, and after feeding were $0.0 \mathrm{~m}, 0.0 \mathrm{~m}$, and $0.0 \mathrm{~m}$ in males, and $1.3 \mathrm{~m}, 0.0 \mathrm{~m}$, and $0.5 \mathrm{~m}$ in females, respectively. In females, values before and after feeding were significantly $(\mathrm{P}<0.05)$ larger than that at feeding. Before feeding, females showed a significantly $(\mathrm{P}<0.05)$ longer flight distance than males. Males seem to have almost no wariness of caretakers in contrast to females, which seem to be not so wary of caretakers only at feeding. Since the capture time of females $(52.8 \mathrm{sec})$ was significantly $(\mathrm{P}<$ $0.01)$ longer than that of males $(6.4 \mathrm{sec})$, it was supported further that females are warier of people than males. Since all the maximum values in approach distance, flight distance, and capture time were observed in the animals of 3 to 4 years old, it was presumed that sheep's wariness of people becomes highest at around 3 to 4 years old. 